\title{
Penerapan Media Gambar Sebagai Upaya dalam Peningkatan Konsentrasi Belajar Anak Usia Dini
}

\author{
Sita Husnul Khotimah ${ }^{\circledR}$, Titin Sunaryati ${ }^{2}$, Sri Suhartini ${ }^{3}$ \\ Pendidikan Guru Madrasah Ibtidaiyah, Sekolah Tinggi Agama Islam AlHikmah Jakarta (1) \\ Pendidikan Guru Sekolah Dasar, Universitas Pelita Bangsa (2) \\ Pendidikan Islam Anak Usia Dini, Sekolah Tinggi Agama Islam AlHikmah Jakarta (3) \\ DOI: $10.31004 /$ obsesi.v5i1.683
}

\begin{abstract}
Abstrak
Tujuan dari penelitian ini adalah untuk mengetahui apakah Media gambar dapat meningkatkan konsentrasi belajar anak di Raudhatul Athfal (RA) Annajmah Kebayoran Lama Jakarta Selatan. Penelitian ini merupakan penelitian tindakan kelas (classroom action research), karena dilakukan untuk memecahkan masalah pembelajaran di kelas. Penelitian ini juga termasuk penelitian deskriptif, sebab menggambarkan sesuatu teknik pembelajaran yang diterapkan dan bagaimana hasil yang diinginkan dapat tercapai. Penelitian dilaksanakan dalam dua siklus dengan prosedur tindakan sebagai berikut, (1) perencanaan, (2) pelaksanaan, (3) pengamatan dan evaluasi, (4) analisis dan refleksi. Hasil penelitian menunjukkan adanya peningkatan konsentrasi belajar anak setelah mengikuti pelaksanaan kegiatan dengan media gambar pada siklus 1 yang mulanya hanya mencapai $70 \%$ mengalami peningkatan yang cukup signifikan yakni mencapai $84 \%$. Hal ini menunjukkan bahwa media gambar dapat digunakan untuk meningkatkan konsentrasi belajar pada anak kelompok B di RA Annajmah Kebayoran Lama.
\end{abstract}

Kata Kunci: konsentrasi belajar; media gambar; anak usia dini.

\begin{abstract}
Purpose of this study is to find out whether the image media can improve the concentration of children's learning at (Raudhatul Athfal) RA Annajmah Kebayoran Old South Jakarta. This research is aclassroom action research, because it is conducted to solve learning problems in class. This research is also a descriptive study, because it illustrates a learning technique that is applied and how the desired results can be achieved. The study was conducted in two cycles with the following action procedures, (1) planning, (2) implementation, (3) observation and evaluation, (4) analysis and reflection. The results showed an increase in the concentration of children's learning after following the implementation of activities with media images in cycle 1 which initially only reached $70 \%$ had a significant increase that reached $84 \%$. This shows that the image media can be used to increase the concentration of learning in group B at RA Annajmah Kebayoran Lama.
\end{abstract}

Keywords: concentration of learning, media images

Copyright (c) 2020 Sita Husnul Khotimah, Titin Sunaryati, Sri Suhartini

$\triangle$ Corresponding author :

Email Address : sita_kh81@yahoo.com ( Jakarta, Indonesia )

Received 27 July 2020, Accepted 7 August 2020, Published 9 August 2020 


\section{PENDAHULUAN}

Pendidikan anak usia dini adalah pendidikan yang ditujukan bagi anak-anak usia prasekolah dengan tujuan agar anak dapat mengembangkan potensi-potensinya sejak dini sehingga mereka dapat berkembang secara wajar sebagai anak. Pembelajaran anak usia dini harus menarik, dengan mengedepankan konsep bermain secara menyenangkan dan bermakna (Lestariningrum 2017). Seorang guru berkewajiban menyediakan media/alat peraga semenarik mungkin sehingga anak tertarik untuk mengikuti proses pembelajaran dan anak mudah memahami maksud dari aktifitas yang akan dilakukan (Madiarti 2013).

Hasil observasi awal yang dilakukan menunjukkan kenyataan bahwa pembelajaran di Raudhatul Athfal (RA) Annajmah Kebayoran Lama Jakarta Selatan seringkali kurang bervariasi, hal ini terlihat dari cara pembelajarannya lebih sering menggunakan LKS. Dari 4 kelas yang terdiri dari 2 kelas kelompok A dan 2 kelas kelompok B, semua guru seragam menggunakan LKS dan buku paket saja dalam pembelajarannya. Hal ini menyebabkan pembelajaran kurang menarik bagi siswa, terbukti beberapa siswa terlihat asik bermain sendiri, dan ada yang terlihat bercanda dengan teman yang lain saat mengejakan LKS. Beberapa hal yang menyebabkan demikian, diantaranya adalah penyajian LKS yang kurang menarik, dan alat peraga yang sangat minim digunakan. Kondisi tersebut mengakibatkan anak didik kurang begitu semangat, bosan dan kurang berkonsentrasi dengan apa yang yang disampaikan guru, akhirnya menyepelekan pelajaran. Hal ini ditunjukkan dari 17 anak dalam satu kelas, hanya 50\% yang tertib dalam mengerjakan LKS dan 53\% yang memperhatikan penjelasan guru dengan baik. Sisanya guru harus terus mengingatkan siswa untuk fokus dengan instruksi berulang kali, hal ini tentunya menguras energi bagi guru.

Media pembelajaran di RA Annajmah Kebayoran Lama Jakarta Selatan belum optimal dimanfaatkan, kegiatan belajar lebih sering menggunakan media papan tulis, buku paket dan Lembar Kerja Siswa (LKS) saja. Padahal terlihat banyak media gambar yang tersedia, akan tetapi gambar-gambar tersebut hanya digunakan sebagai alat bermain siswa saat istirahat dan belum dimanfaatkan sebagai media pembelajaran. Hal ini sejalan dengan permasalahan penelitian lain yang mengungkapkan, guru lebih sering memberikan lembar kerja sebagai media belajar, padahal media dapat dengan mudah dibuat dengan cara memanfaatkan lingkungan sekitar, seperti bahan alam (Fauziah 2013). Pembelajaran yang belum memanfaatkan media secara baik dan hanya sering menggunakan LKS, menyebabkan proses belajar menjadi tidak bervariasi sehingga siswa menjadi bosan dan berakibat tidak memperhatikan apa yang disampaikan guru. Kenyataan seperti ini dapat mempengaruhi proses belajar, semangat dan kemampuan anak dalam konsentrasi belajar serta stres pada guru. Konsentrasi sangat berpengaruh terhadap keberhasilan proses pembelajaran, apabila anak/siswa mengalami kesulitan dalam berkonsentrasi, maka proses belajar menjadi tidak optimal (Nuryana 2010).

Konsentrasi menurut Sugiyanto adalah pemusatan pikiran pada suatu hal dengan cara menyampingkan hal-hal lain yang tidak dibutuhkan (Nuryana 2010).. Menurut Prastiti dan Yuwono, konsentrasi merupakan pemusatan perhatian dalam jangka waktu lama (Febriani, Syafar, and Rukiyah 2019). Konsentrasi juga dapat diartikan sebagai kemampuan memusatkan perhatian dalam jangka waktu lama untuk menyelesaikan tugas tanpa merasa terganggu oleh stimulus dari luar maupun dari dalam individu. Pendapat lain menegaskan bahwa konsentrasi belajar adalah fokus perhatian dan kesadaran penuh dari siswa terhadap materi pelajaran yang sedang dipelajari (Erwiza, Kartiko, and Gimin 2019). Super dan Crities (dalam Latifah and Habib 2014), menyebutkan cici-ciri siswa yang memiliki konsentrasi belajar yang baik adalah sebagai berikut, 1) memperhatikan setiap materi pelajaran yang disampaikan guru, 2) dapat merespon dan memahami setiap materi pelajaran yang diberikan, 3) selalu bersikap aktif dengan bertanya dan memberikan argumentasi mengenai materi pelajaran yang disampaikan guru, 4) menjawab dengan baik dan benar setiap pertanyaan yang diberikan guru, dan 5) kondisi kelas tenang dan tidak gaduh saat menerima materi pelajaran. 
Sulitnya anak berkonsentrasi dalam belajar salah satunya disebabkan oleh pengajaran guru yang tidak menarik dan membosankan (Latifah and Habib 2014). Kecenderungan anakanak RA yang tidak bisa duduk diam di kelas adalah biasa, sebagian besar aktivitas anak usia prasekolah menggunakan gerak fisik dan bermain (Miftahillah 2017). Agak sulit untuk anak bisa duduk diam di waktu yang lama dan berkonsentrasi. Meskipun begitu anak-anak prasekolah boleh diajarkan untuk duduk diam dan memperhatikan. Untuk anak RA sebaiknya memang dipersiapkan untuk menerima sistem belajar di SD. Dimana murid-murid dituntut untuk tidak lagi ribut atau berlarian di kelas. Tetapi tentunya pengenalan itu hanya bisa dilakukan secara bertahap. Kita tidak bisa memaksakan anak untuk langsung untuk disuruh duduk diam dan berjalan-jalan di kelas.

Konsentrasi sangat penting dan dibutuhkan bagi siswa dalam mengikuti proses pembelajaran, agar kompetensi yang diharapkan dapat dikuasainya dengan baik. Begitu pentingnya konsentrasi bagi siswa, sehingga konsentrasi merupakan prasyarat bagi siswa agar dapat belajar dan berhasil mencapai tujuan pembelajaran. Selain itu konsentrasi belajar merupakan hal penting bagi siswa karena menentukan prestasi belajarnya, konsentrasi belajar tersebut dapat dilihat dari fokusnya siswa belajar (Hasanah, Ahmad, and Karneli 2017). Petersan (2010), menyatakan bahwa rendahnya prestasi belajar siswa sebagian besar disebabkan oleh lemahnya kemampuan anak untuk berkonsentrasi (Erwiza et al. 2019). Konsentrasi belajar menurut Dimyati (2009) merupakan kemampuan memusatkan perhatian pada pelajaran, pemusatan perhatian tersebut tertuju pada isi bahan belajar maupun proses memperolehnya (Setiani, Setyowani, and Kurniawan 2014). Jika seorang siswa tidak dapat berkonsentrasi dalam belajar, bisa jadi ia tidak dapat menikmati proses belajar yang dilakukannya.

Upaya yang harus ditempuh dalam meningkatkan konsentrasi adalah guru harus menyiapkan media pembelajaran sebagai alat bantu utama untuk menunjang keberhasilan mengajar, serta mengembangkan metode yang dipakai dengan memanfaatkan media. Berhasilnya suatu pembelajaran sangat berpengaruh dari penggunaan media pembelajaran (Amir 2016). Di tangan gurulah alat-alat itu bermakna untuk menambah pengetahuan, ketrampilan dan konsentrasi belajar pada anak. Di samping itu guru mempunyai peran sebagai pengajar, mendidik, melatih, dan mengevaluasi. Penggunaan media dalam proses pembelajaran dapat membangkitkan minat dan rasa ingin tahu yang baru, menumbuhkan motivasi dan rangsangan kegiatan belajar, serta membawa pengaruh psikologis terhadap pembelajaran (Falahudin 2014).

Sebagai sosok pengganti orang tua, di sekolah guru harus dapat mengendalikan situasi. Pembelajaran yang berhasil sekaligus menyenangkan memerlukan sebanyakbanyaknya media belajar. Media belajar juga berfungsi memudahkan terjadinya proses pembelajaran. Kesimpulan dari berbagai penelitian yang dilakukan terhadap penggunaan media dalam pembelajaran, menunjukkan perbedaan yang signifikan antara pembelajaran tanpa media dengan pembelajaran menggunakan media terhadap proses dan hasil belajar pada siswa (Zaman, Pd, and Eliyawati 2010). Oleh karena itu penggunaan media pembelajaran sangat dianjurkan untuk mempertinggi kualitas pembelajaran. Penentuan media belajar harus dipilih, disaring dan diselaraskan dengan tujuan yang ingin dicapai. Maka dari itu hendaknya dipilih alat bantu yang memiliki ciri-ciri sebagai berikut, a) menarik perhatian dan minat siswa; b) meletakkan dasar-dasar untuk memahami sesuatu hal secara konkret, sekaligus mencegah atau mengurangi verbalisme; c) sederhana, mudah digunakan dan dirawat serta dapat dibuat sendiri oleh guru atau diambil dari lingkungan sekitar (Emda 2011).

Salah satu cara yang paling efektif dalam pengelola kelas yang kurang berkonsentrasi yaitu dengan cara memberikan media yang menarik bagi anak yaitu Media gambar. Hal ini sejalan dengan hasil penelitian yang menyatakan bahwa penggunaan media gambar dapat meningkatkan hasil belajar siswa (Dwi P and Subagio 2013). Gambar ini merupakan alat visual yang efektif karena dapat divisualisasikan sesuatu yang akan dijelaskan dengan lebih konkrit 
dan realistis. Informasi yang disampaikan dapat dimengerti dengan mudah karena hasil yang diragakan lebih mendekati kenyataan melalui foto yang diperlihatkan kepada anak-anak, dan hasil yang diterima oleh anak-anak akan sama. Sekumpulan gambar terpisah yang memuat satuan-satuan gambar serta mewakili serentetan cerita adalah definisi dari media gambar menurut Madyawati (Godvany, Nuryana, and Gunatama 2014). Media gambar adalah media yang paling umum dipakai. Hal ini dikarenakan siswa lebih menyukai gambar daripada tulisan, apalagi jika gambar dibuat dan disajikan sesuai dengan persyaratan yang baik, sudah tentu akan menambah semangat siswa dalam mengikuti proses pembelajaran. Penggunaan media gambar sebaiknya harus disesuaikan dengan kematangan siswa.

Gambar yang digemari dan menarik perhatian anak usia dini adalah gambar berwarna, melukiskan situasi nyata, jarak serta ukuran besar kecil antar gambar harus jelas (Gusmita 2018). Anak-anak kelas rendah memiliki ketertarikan yang tinggi terhadap warnawarna yang mencolok. Warna merupakan salah satu elemen yang memegang peranan penting dalam menstimulasi perkembangan anak (Julianto et al. 2019). Sementara melalui penggunaan media gambar dalam pembelajaran guru bisa menggunakan media gambar untuk menumbuhkan perhatian, Ketelitian dan Ketertiban anak sehingga konsentrasi belajar anak dapat meningkat.

Fungsi utama media belajar ialah memvisualisasikan sesuatu yang tidak dapat dilihat atau sukar dilihat sehingga tampak jelas dan dapat menimbulkan pengertian atau meningkatkan persepsi seseorang (Tafonao 2018). Media gambar dirasa lebih efektif digunakan dalam pembelajaran, hal ini dikarenakan anak sekarang lebih suka menonton film animasi yang lucu dan menarik dengan gambar yang bervariasi. Penelitian sebelumnya sudah banyak membahas tentang media gambar, akan tetapi lebih fokus untuk peningkatan hasil belajar.

Pada umumnya penilaian pembelajaran hanya dilakukan terhadap hasil belajar siswa. Padahal, hasil belajar siswa diperoleh setelah melalui serangkaian proses belajar. Siswa yang mendapat hasil belajar kurang baik bisa saja sebenarnya disebabkan karena proses belajar yang tidak maksimal. Berdasarkan pertimbangan tersebut, penelitian ini bertujuan untuk mengetahui apakah media gambar dapat meningkatkan konsentrasi belajar anak kelompok B di RA Annajmah Kebayoran Lama Jakarta Selatan. Melalui pembelajaran media gambar diharapkan anak dapat berkonsentrasi lebih lama dalam proses belajar. Dengan meningkatnya konsetrasi belajar pada saat pembelajaran diharapkan hasil belajar siswa menjadi meningkat pula.

\section{METODOLOGI}

Penelitian ini adalah penelitian tindakan kelas (classroom action research), karena penelitian dilakukan untuk memecahkan masalah pembelajaran di kelas. Penelitian ini juga termasuk penelitian deskriptif, sebab menggambarkan sesuatu teknik pembelajaran yang diterapkan dan bagaimana hasil yang diinginkan dapat tercapai. Penelitian dilaksanakan di RA Annajmah Kebayoran Lama Jakarta Selatan, dengan subjek penelitian adalah siswa RA kelompok B yang berjumlah 17 anak (satu kelas). Penelitian ini dilaksanakan pada bulan November 2019 sampai dengan Januari 2020 dengan melalui empat prosedur yaitu perencanan, pelaksanaan, pengamatan dan refleksi. Penelitian dilakukan dalam dua siklus, dengan masing-masing siklus sebanyak tiga kali pertemuan. Pada penelitian tindakan ini peneliti berperan sebagai guru dan penanggung jawab penuh penelitian, adapun kolaboratornya adalah guru kelas sebagai observer dalam pelaksanaan pembelajaran. Siklus pada penelitian ini mengadopsi dari Arikunto (2007) dalam (Febriyantika 2013), gambar dapat dilihat pada bagan berikut: 


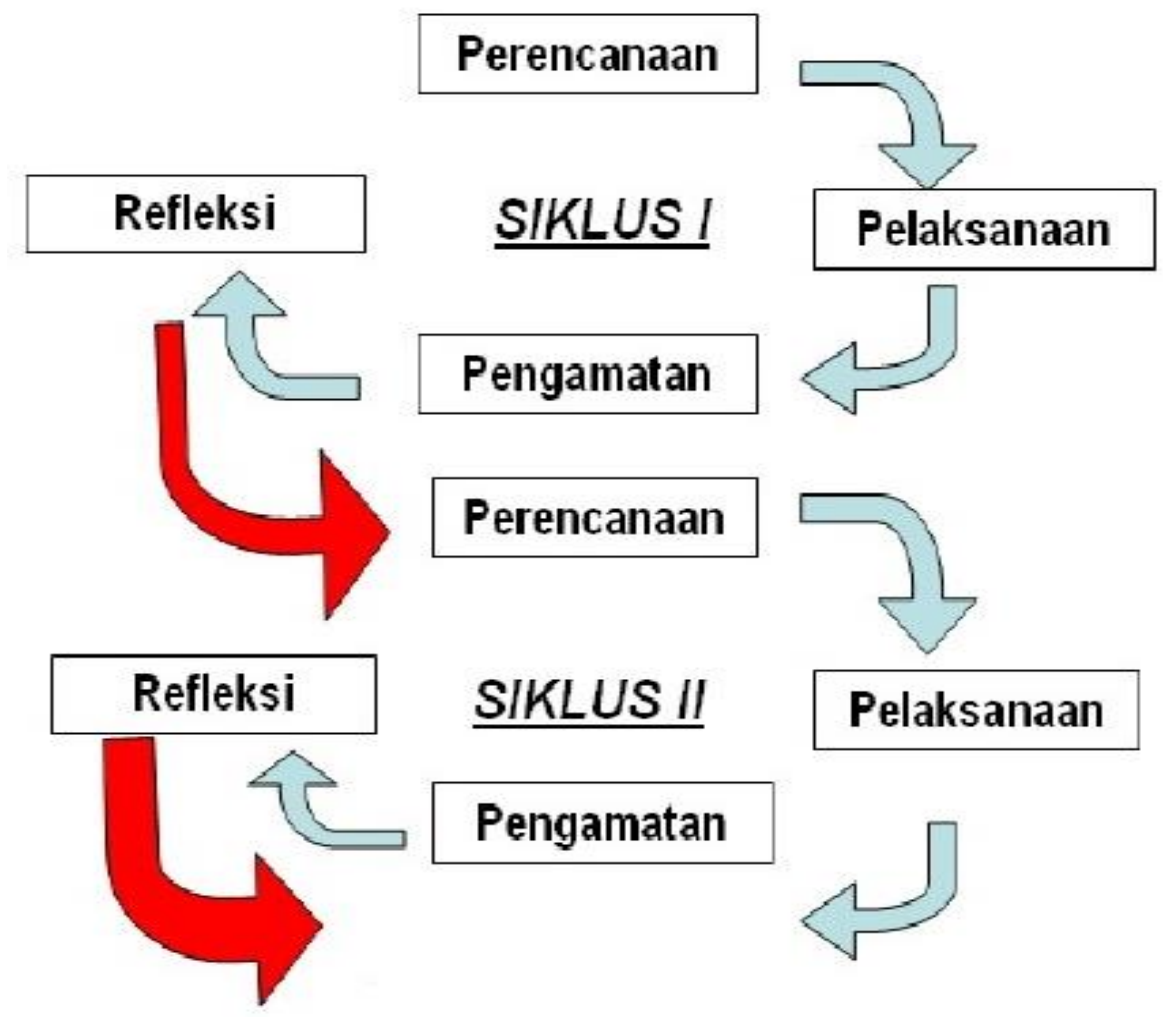

Gambar 1. Alur Siklus Penelitian Tindakan Kelas

Teknik pengumpulan data melalui dokumentasi dan observasi, selanjutnya dianalisis dengan menggunakan statistik sederhana yaitu, penjumlahan nilai yang diperoleh peserta didik, yang selanjutnya dibagi dengan jumlah anak yang ada di kelas. Indikator keberhasilan dalam penelitian ini adalah konsentrasi belajar anak pada akhir siklus dikatakan meningkat apabila dalam proses pembelajaran terlihat adanya peningkatan jumlah siswa yang konsentrasi belajarnya baik dari siklus 1 ke siklus berikutnya dengan kriteria 75\% dari total anak dalam kelas, jika target tercapai berarti siklus dihentikan. Skala penilaian konsentrasi belajar siswa dapat dilihat pada tabel berkut:

Tabel 1. Kriteria Tingkat Ketercapaian Konsentrasi Belajar Siswa dalam Persen (\%)

\begin{tabular}{ccc}
\hline No & Tingkat Ketercapaian & Skor \\
\hline 1 & $86-100$ & Sangat Baik \\
2 & $71-85$ & Baik \\
3 & $56-70$ & Cukup \\
4 & $41-55$ & Kurang \\
5 & $26-40$ & Kurang Sekali \\
\hline \multicolumn{2}{l}{ (Adaptasi dari Aqib, dkk dalam (Rahmawati, Pitadjeng, and Nugraheni 2014) }
\end{tabular}

\section{HASIL DAN PEMBAHASAN}

\section{Hasil Penelitian Awal}

Sebelum dilaksanakan tindakan dengan media gambar, dilakukan observasi awal untuk mengetahui konsentrasi anak. Hasil observasi awal diperoleh hasil sebagai berikut: 
Penerapan Media Gambar Sebagai Upaya dalam Peningkatan Konsentrasi Belajar Anak Usia Dini DOI: $10.31004 /$ obsesi.v5i1.683

Tabel 1. Hasil Observasi Awal Konsentrasi Belajar Anak

\begin{tabular}{ccccc}
\hline No & \multicolumn{3}{c}{ Aspek yang diamati } & Jumlah \\
& Perhatian & Ketelitian & Ketertiban & Skor \\
\hline 1 & 1 & 1 & 1 & 3 \\
2 & 3 & 2 & 2 & 7 \\
3 & 2 & 2 & 2 & 6 \\
4 & 2 & 2 & 2 & 6 \\
5 & 1 & 1 & 1 & 3 \\
6 & 1 & 1 & 1 & 3 \\
7 & 1 & 2 & 2 & 5 \\
8 & 1 & 1 & 1 & 3 \\
9 & 3 & 2 & 3 & 8 \\
10 & 2 & 1 & 2 & 5 \\
11 & 2 & 2 & 1 & 5 \\
12 & 1 & 1 & 2 & 4 \\
13 & 1 & 1 & 1 & 3 \\
14 & 4 & 3 & 4 & 11 \\
15 & 4 & 4 & 4 & 12 \\
16 & 3 & 2 & 1 & 6 \\
17 & 4 & 2 & 4 & 10 \\
\hline Jumlah Skor & 36 & 30 & 34 & 100 \\
Rata-Rata & 2,12 & 1,76 & 2 & 1,96 \\
Prosentase (\%) & 53 & 44 & 50 & 49 \\
\hline
\end{tabular}

Berdasarkan hasil di atas dapat dilihat bahwa prosentase kelas diperoleh pada angka $49 \%$ untuk anak yang memiliki konsentrasi baik. Hal ini menunjukkan konsentrasi belajar siswa masih sangat rendah dan memerlukan tindakan guru agar siswa dapat lebih konsentrasi dalam pembelajaran, yaitu dengan memfasilitasi siswa dengan media gambar sebagai media pembelajaran.

\section{Hasil Siklus I}

Hasil pengamatan konsentrasi siswa pada siklus I di pertemuan pertma dan kedua dalam kegiatan mencari perbedaan pada media gambar yang dibagikan dengan tepat dapat dilihat pada tabel di bawah ini:

Tabel 2. Hasil Konsentrasi Belajar Siswa dengan Media Gambar

\begin{tabular}{ccccccccccccc}
\hline Pertemuan & \multicolumn{1}{c}{ Perhatian } & \multicolumn{1}{c}{ Aspek yang Diamati } \\
& \multicolumn{3}{c}{ Ketelitian } & \multicolumn{3}{c}{ Ketertiban } \\
& SB & B & C & K & SB & B & C & K & SB & B & C & K \\
\hline I & 6 & 6 & 5 & 0 & 1 & 5 & 10 & 1 & 2 & 7 & 8 & 0 \\
& $35 \%$ & $35 \%$ & $29 \%$ & $0 \%$ & $6 \%$ & $29 \%$ & $59 \%$ & $6 \%$ & $12 \%$ & $41 \%$ & $47 \%$ & $0 \%$ \\
\hline Rata-rata & 3,06 & & & & 2,35 & & & & 2,65 & & \\
Prosentase & $76 \%$ & & & & $59 \%$ & & & & $67 \%$ & & \\
\hline II & 7 & 5 & 5 & 0 & 1 & 6 & 9 & 1 & 5 & 5 & 7 & 0 \\
& $41 \%$ & $29 \%$ & $29 \%$ & $0 \%$ & $6 \%$ & $35 \%$ & $53 \%$ & $6 \%$ & $29 \%$ & $29 \%$ & $41 \%$ & $0 \%$ \\
\hline Rata-rata & 3,12 & & & & 2,41 & & & & 2,88 & & & \\
Prosentase & $78 \%$ & & & & $60 \%$ & & & & $72 \%$ & & \\
\hline
\end{tabular}

Berdasarkan tabel 2. di atas dapat dilihat skor rata-rata kelas pada aspek pertama adalah sebesar 3,06 yang berarti baik dengan prosentase sebesar $76 \%$, dan aspek kedua mendapat rata-rata kelas sebesar 2,35 yang berarti cukup sebesar 59\%, dan aspek ketiga 
memperoleh nilai rata-rata sebesar 2,65 yang berarti cukup sebesar $66 \%$. Sedangkan dalam penilaian secara keseluruhan konsentrasi siswa pada pertemuan pertama siklus I diperoleh nilai sebesar 2,69 sebanyak $67 \%$ yang berarti konsentrasi anak masih dalam kategori cukup saja.

Sedangkan pada pertemuan kedua, dilihat skor rata-rata kelas pada aspek pertama sebesar 3,12 yang berarti baik dengan prosentase sebesar 78\%, dan aspek kedua mendapat rata-rata kelas sebesar 2,41 yang berarti cukup sebesar $60 \%$ dan aspek ketiga memperoleh nilai rata-rata sebesar 2,88 yang berarti cukup sebesar $72 \%$. Sedangkan dalam penilaian secara keseluruhan konsentrasi anak pada pertemuan kedua siklus I diperoleh nilai sebesar 2,80 sebanyak $70 \%$ yang berarti konsentrasi anak masih dalam kategori cukup saja. Dari keseluruhan siklus I diketahui adanya kemajuan konsentrasi anak dalam belajar, tetapi peningkatan konsentrasi belajar siswa termasuk masih dalam kategori cukup sehingga perlu pelaksanaan tindakan selanjutnya.

Sistematika pembelajaran yang dilakukan oleh guru pada siklus I sudah baik selama pelaksanaanya, namun fokus perhatian guru kurang menyeluruh kepada anak sehingga masih ditemukan beberapa anak yang tidak fokus terhadap kegiatannya atau dilihat kurang percaya diri dengan tugas yang diberikan kepada anak, sehingga anak masih melihat-lihat tugas yang dikerjakan temannya dan sesekali berlarian ke sana kemari untuk melihat pekerjaan yang dilakukan oleh teman. Guru perlu melaksanakan pendekatan individu, anak dapat ditanya apa saja yang membuatnya fokus. Jangan tanyakan anak mengapa anak tidak fokus, tetapi tanyakan bagaimana agar anak mau mengerjakan suatu tugas sampai dengan selesai. Dengan begitu, guru dapat mulai mencari aktivitas lain yang akan memancing fokus anak. Amati kondisi seperti apa yang dibutuhkan anak ketika anak dapat fokus.

Pada siklus I menerapkan media gambar berupa mencari perbedaan pada dua gambar yang mirip dengan tepat. Perubahan yang terjadi pada peningkatan angka persentase kategori baik mempengaruhi persentase kategori cukup. Untuk kategori kurang angka persentasenya tidak mengalami perubahan. Hasil analisa data yang diperoleh dari siklus I menunjukan belum tercapainya indikator keberhasilan yang di tentukan dalam penelitian tindakan kelas ini yaitu minimal sebesar $75 \%$ dari keseluruhan jumlah siswa. Dengan demikian maka di butuhkan siklus kedua sebagai lanjutan dari siklus pertama. Diharapkan dengan adanya siklus kedua akan terjadi peningkatan lagi pada tingkat konsentrasi belajar anak.

\section{Hasil Siklus II}

Penelitian tindakan dilanjutkan pada siklus kedua untuk mendapatkan hasil konsentrasi belajar yang optimal dan sesuai dengan indikator keberhasilan penelitian yang sudah ditetapkan oleh peneliti sebelumnya. Pada siklus 2, kegiatan pembelajaran berupa Mencari perbedaan pada media gambar yang dibagikan dengan tepat. Setelah dilakukan kegiatan pembelajaran maka terjadi peningkatan hasil seperti yang tertera pada tabel di bawah ini.

Tabel 3. Hasil Konsentrasi Belajar Siswa dengan Media Gambar

\begin{tabular}{|c|c|c|c|c|c|c|c|c|c|c|c|c|}
\hline \multirow[t]{3}{*}{ Pertemuan } & \multicolumn{12}{|c|}{ Aspek yang diamati } \\
\hline & \multicolumn{4}{|c|}{ Perhatian } & \multicolumn{4}{|c|}{ Ketelitian } & \multicolumn{4}{|c|}{ Ketertiban } \\
\hline & SB & B & $\mathrm{C}$ & $\mathrm{K}$ & SB & B & $\mathrm{C}$ & $\mathrm{K}$ & SB & B & $\mathrm{C}$ & $\mathrm{K}$ \\
\hline \multirow[t]{2}{*}{ I } & 7 & 7 & 3 & 0 & 4 & 9 & 4 & 0 & 6 & 8 & 3 & 0 \\
\hline & $41 \%$ & $41 \%$ & $18 \%$ & $0 \%$ & $24 \%$ & $53 \%$ & $24 \%$ & $0 \%$ & $35 \%$ & $47 \%$ & $18 \%$ & $0 \%$ \\
\hline Rata-rata & 3,24 & & & & 3 & & & & 3,18 & & & \\
\hline Prosentase & $81 \%$ & & & & $75 \%$ & & & & $78 \%$ & & & \\
\hline \multirow[t]{2}{*}{ II } & 9 & 8 & 0 & 0 & 5 & 9 & 3 & 0 & 10 & 4 & 3 & 0 \\
\hline & $53 \%$ & $47 \%$ & $0 \%$ & $0 \%$ & $29 \%$ & $53 \%$ & $18 \%$ & $0 \%$ & $59 \%$ & $24 \%$ & $18 \%$ & $0 \%$ \\
\hline Rata-rata & 3,53 & & & & 3,12 & & & & 3,41 & & & \\
\hline Prosentase & $88 \%$ & & & & $78 \%$ & & & & $85 \%$ & & & \\
\hline
\end{tabular}


Berdasarkan tabel 3. di atas dapat dilihat skor rata-rata kelas pada aspek pertama adalah sebesar 3,24 yang berarti dalam kategori baik dengan prosentase sebesar $81 \%$, dan aspek kedua mendapat rata-rata kelas sebesar 3,00 yang berarti dalam kategori baik sebesar $75 \%$ dan aspek ketiga memperoleh nilai rata-rata sebesar 3,18 yang berarti dalam kategori baik sebesar $79 \%$. Sedangkan dalam penilaian secara keseluruhan konsentrasi anak pada pertemuan pertama siklus II diperoleh nilai sebesar 3,14 sebanyak $78 \%$ yang berarti konsentrasi anak sudah dalam kategori Baik.

Sedangkan pada pertemuan kedua, skor rata-rata kelas pada aspek pertama sebesar 3,53 yang berarti kategori baik dengan prosentase sebesar $88 \%$, dan aspek kedua mendapat rata-rata kelas sebesar 3,12 yang berarti kategori baik sebesar $78 \%$ dan aspek ketiga memperoleh nilai rata-rata sebesar 3,41 yang berarti dalam kategori baik sebesar 85\%. Sedangkan dalam penilaian secara keseluruhan konsentrasi anak pada pertemuan kedua siklus II diperoleh nilai sebesar 3,35 sebanyak $84 \%$ yang berarti konsentrasi anak sudah dalam kategori Baik. Anak yang sulit fokus bukan hanya terganggu oleh faktor eksternal seperti teman sekelas, tetapi ada juga faktor dari dirinya sendiri. Anak dapat tiba-tiba terpikir suatu hal lain saat sedang asik mengerjakan sesuatu kemudian langsung bergerak atau beralih perhatian, dan juga ada yang justru pasif saat pembelajaran. Bersifat pasif dalam belajar, artinya siswa tidak pernah bertanya ketika ada bagian materi pelajaran yang tidak dimengerti siswa (Setiani et al. 2014).

Dari hasil penelitian dapat dilihat meskipun masih ada anak yang belum bisa fokus (memperhatikan dengan baik) dan mengingat pembelajaran yang sudah dilakukan, tetapi tingkat keberhasilan sudah mencapai $84 \%$ untuk kategori baik dan sangat baik, sehingga tidak diperlukan siklus berikutnya dan penelitian tindakan dihentikan. Rangkuman hasil peningkatan tiap siklus dapat dilihat pada tabel di bawah ini:

Tabel 4. Peningkatan Konsentrasi Belajar Siswa Slkus I dan II

\begin{tabular}{lcc}
\hline \multicolumn{1}{c}{ Siklus } & Rata-rata & Prosentase \\
\hline Pra Siklus & 1,96 & $49 \%$ \\
\hline I & 2,8 & $70 \%$ \\
\hline II & 3,35 & $84 \%$ \\
\hline
\end{tabular}

Dari tabel di atas maka diketahui bahwa adanya peningkatan konsentrasi belajar anak setelah mengikuti pelaksanaan kegiatan baik siklus I maupun siklus II. Pada siklus I yang mulanya hanya mencapai $70 \%$ mengalami peningkatan yang cukup signifikan yakni mencapai $84 \%$.

Berdasarkan paparan data penelitian tindakan kelas di atas, dapat dianalisa dengan cara membandingkan hasil dari proses pembelajaran pada siklus I dan siklus II menunjukan adanya peningkatan konsentrasi belajar anak setelah diterapkannya pembelajaran dengan media gambar. Sejalan dengan hasil penelitian yang menyatakan, bahwa dengan memanfaatkan media gambar dapat meningkatkan keterlaksanaan pembelajaran (Nurhayani and Sukidi 2013). Hasil penelitian terdahulu juga menunjukkan peranan media gambar mampu menarik perhatian siswa dengan baik sehingga mendukung tercapainya proses pembelajaran yang efektif (Wanti and Haris 2013). Sebelum diterapkannya pembelajaran dengan media gambar sebagian besar anak kurang berkonsentrasi dalam belajar. Mereka terkadang lebih mementingkan kesibukan mereka sendiri dari pada memperhatikan apa yang disampaikan oleh guru. Hal ini senada dengan pendapat Robert Dilts dalam Simatupang, yang menyatakan bahwa kesulitan konsentrasi dipengaruhi beberapa hal yaitu, 1) seorang anak memiliki terlalu banyak gangguan dan kekhawatiran, 2) ingin melakukan sesuatu yang lain, 3) merasa lelah, 4) merasa lapar, 5) kecanduan teknologi (Simatupang, Ramadhani, and Manurung 2019). Menanggapi permasalahan tersebut maka dengan diterapkannya media gambar maka konsentrasi belajar anak menjadi meningkat. 
Peningkatan tersebut juga cukup signifikan karena dapat mencapai indikator keberhasilan dengan skor yang melebihi skor indikator terendah dalam ketentuan penelitian yaitu $75 \%$.

Siklus II menerapkan media gambar berupa mencari perbedaan pada dua gambar yang mirip dengan tepat. Angka persentase setiap aspek yang diteliti sudah melebihi batas minimal indikator keberhasilan. Dengan demikian penelitian ini dinyatakan berhasil. Semua kegiatan membutuhkan konsentrasi, dengan konsentrasi kegiatan tersebut dapat dikerjakan lebih cepat dan hasil yang diperoleh bisa lebih baik, oleh karena itu konsentrasi sangat penting dan perlu dilatih. Sejalan dengan pendapat Musbikin dalam Fitri, mengungkapkan bahwa konsentrasi sangat penting dalam kehidupan manusia, karena berkaitan dengan usaha manusia tanpa terkecuali terhadap suatu hal. Demikian juga Anak usia dini memfokuskan perhatian pada suatu objek yang ditunjukkan, sehingga dapat memahami dan mengerti objek yang diperlihatkan (Aviana and Hidayah 2015). Untuk merangsang semua aspek perkembang anak usia dini tidak bisa lepas dari media pembelajaran karena bagi anak usia dini belajar dilakukan melalui bermain dengan menggunakan media pembelajaran, baik media nyata, media audio, media visual, media lingkungan sekitar maupun media audio visual, sehingga kegiatan pembelajaran pada anak usia dini berjalan secara efektif (Dewi 2017).

\section{SIMPULAN}

Penerapanmedia gambar dapat meningkatkan konsentrasi belajar anak kelompok B RA Annajmah Kebayoran Lama. Hal ini ditandai dan dibuktikan dengan adanya peningkatan angka persentase konsentrasi anak dalam belajar. Konsentrasi anak dari siklus 1 meningkat pada siklus 2. Peningkatan konsentrasi belajar anak setelah mengikuti pelaksanaan kegiatan menggunakan media gambar cukup signifikan. Hal ini menunjukkan bahwa media gambar dapat digunakan untuk meningkatkna konsentrasi belajar pada anak usia dini.

\section{UCAPAN TERIMA KASIH}

Terimakasih untuk Ibu Kepala Sekolah dan para guru RA Annajmah Kebayoran Lama Jakarta Selatan yang telah membantu proses penelitian ini.

\section{DAFTAR PUSTAKA}

Amir, Almira. 2016. "Penggunaan Media Gambar Dalam Pembelajaran Matematika." Jurnal Eksakta 2(1):34-40.

Aviana, Ria, and Fatichatul Fitria Hidayah. 2015. "Pengaruh Tingkat Konsentrasi Belajar Siswa Terhadap Daya Pemahaman Materi Pada Pembelajaran Kimia Di SMA Negeri 2 Batang." Jurnal Pendidikan Sains 03:1-4.

Dewi, Kurnia. 2017. "Pentingnya Media Pembelajaran." Jurnal Pendidikan Anak Usia Dini 1(2):1-4.

Dwi P, R. A., and FX. M. Subagio. 2013. “Penggunaan Media Gambar Untuk Meningkatkan Proses Pembelajaran Tema Tanaman Dan Binatang Di Sekolah Dasar [The Use of Image Media to Improve Learning Proccess in Animal and Tree Themes in Elementary Schools." Jurnal Pendidikan Guru Sekolah Dasar 1(2):1-19.

Emda, Amna. 2011. "Pemanfaatan Media Dalam Pembelajaran Biologi Di Sekolah." Jurnal Ilmiah Didaktika 12(1):149.

Erwiza, Erwiza, Sri Kartiko, and Gimin Gimin. 2019. "Factors Affecting the Concentration of Learning and Critical Thinking on Student Learning Achievement in Economic Subject." Journal of Educational Sciences 3(2):205.

Falahudin, Iwan. 2014. “Pemanfaatan Media Dalam Pembelajaran.” Jurnal Lingkar Widyaiswara 1(4):104-17.

Fauziah, Nadia. 2013. "Penggunaan Media Bahan Alam Untuk Meningkatkan Kreativitas Anak." Jurnal Ilmiah Visi P2TK PAUD NI 8(1):23-30. 
Febriani, Fricilia, Syafdaningsih Syafar, and Rukiyah. 2019. "PENGEMBANGAN PERMAINAN PESAN BERANTAI UNTUK KONSENTRASI ANAK DI KELOMPOK A TK KARTIKA II-1 PALEMBANG." Jurnal Tumbuh Kembang : Kajian Teori Dan Pembelajaran PAUD.

Febriyantika, Fenny P. 2013. “Upaya Peningkatan Motivasi Belajar Siswa Dalam Pembelajaran Ekonomi Dengan Menggunakan Metode Word Square (PTK Pada Siswa Kelas VIII H Semester Genap Di Madrasah Tsanawiyah Negeri Suarakarta 1 Tahun Ajaran 2012/2013)."

Godvany, Nilla, I. Gede Nuryana, and Gede Gunatama. 2014. “Meningkatkan Keterampilan Menulis Karangan Deskripsi Melalui Kegiatan Belajar Di Luar Kelas Dengan Pendekatan Kontekstual Pada Siswa Kelas VII SMP Negeri 1 Sukasada." Jurnal Pendidikan Bahasa Dan Sastra Indonesia Undiksha 6(1).

Gusmita, Dewi Elia. 2018. "Penggunaan Media Gambar Berwarna Dalam Meningkatkan Kemampuan Mengenal Warna Di PAUD WITRI 1 Kota Bengkulu." Instititut Agama Islam Negeri Bengkulu.

Hasanah, Ummi, Riska Ahmad, and Yeni Karneli. 2017. “Efektivitas Layanan Penguasaan Konten Untuk Meningkatkan Konsentrasi Belajar Siswa." International Conseling and Education Seminar 143-48.

Julianto, I. Nyoman Larry, I. Wayan Agus, Eka Cahyadi, and Cokorda Alit Artawan. 2019. "Interaktivitas Warna Sebagai Rangsang Visual Pada Ruang Belajar Siswa Sekolah Dasar Kelas 1 - 3 Di Kota Denpasar." Seminar Nasional Sandyakala 56-64.

Latifah, Khuzaimatul, and Zainal Habib. 2014. "Hubungan Persepsi Terhadap Keterampilan Guru Mengajar Dengan Konsentrasi Belajar Siswa Di Darul Karomah Randuagung Singosasri Malang." Psikoislamika : Jurnal Psikologi Dan Psikologi Islam 11(1):15-22.

Lestariningrum, Anik. 2017. "Strategi Pengembangan Nilai-Nilai Karakter Anak Usia Dini." Seminar Nasional Pendidikan Dan Kewarganegaraan Iv 81-87.

Madiarti. 2013. "Summary for Policymakers." Pp. 1-30 in Climate Change 2013 - The Physical Science Basis. Vol. 53, edited by Intergovernmental Panel on Climate Change. Cambridge: Cambridge University Press.

Miftahillah. 2017. “Relasi Pendidikan Orang Tua Dengan Perkembangan Fisik Motorik Anak Usia 5-6 Tahun Di RA Kabupaten Pasuruan." Proceedings Ancoms (110):920-31.

Nurhayani, Evana, and Masengut Sukidi. 2013. "Penggunaan Media Gambar Untuk Meningkatkan Keterampilan Menulis Paragraf Deskripsi Siswa Sekolah Dasar Pekanbaru." JPGSD2 1(2):44.

Nuryana, Aryati. 2010. “Efektivitas Brain Gym Dalam Meningkatkan Konsentrasi Belajar Pada Anak." Indigenous, Ilmiah Berkala Psikologi VOl.12 No.:88-98.

Rahmawati, Lisa Nor, Pitadjeng, and Nursiwi Nugraheni. 2014. "Peningkatan Kualitas Pembelajaran Geometri Melalui Kepala Bernomor Terstruktur Berbantuan Media Audio Visual." Joyful Learning Journal 2(5):10-17.

Setiani, Amalia Cahya, Ninik Setyowani, and Kusnarto Kurniawan. 2014. "Meningkatkan Konsentrasi Belajar Melalui Layanan Bimbingan Kelompok." Indonesian Journal of Guidance and Counseling 3(1):39-44.

Simatupang, Dorlince, Rizki Ramadhani, and Mariana Putri Manurung. 2019. “An Effort to Increase the Concentration of Children at 5-6 Years Old Using the Storytelling Methods at ST Theresia Kindergarten Binjai T . A 2014 / 2015." 0:68-74.

Tafonao, Talizaro. 2018. "Peranan Media Pembelajaran Dalam Meningkatkan Minat Belajar Mahasiswa." Jurnal Komunikasi Pendidikan 2(2):103.

Wanti, Andi Sri Wahyu, and Hasnawi Haris. 2013. "Peranan Media Gambar (Visual) Dalam Meningkatkan Konsentrasi Belajar Siswa Pada Mata Pelajaran PKn Di SMP N 1 Sungguminasa Kabupaten Gowa." Journal of Petrology 369(1):1689-99.

Zaman, Badru, M. Pd, and Hj Cucu Eliyawati. 2010. "Media Pembelajaran Anak Usia Dini." Media Pembelajaran Anak Usia Dini 34. 